\title{
Possible roles of insulin and insulin-like growth factors in rat preimplantation development: investigation of gene expression by reverse transcription-polymerase chain reaction
}

\author{
X. Zhang ${ }^{1 *}$, G. M. Kidder ${ }^{2}$, A. J. Watson ${ }^{3}$, G. A. Schultz ${ }^{3}$ and \\ D. T. Armstrong ${ }^{1}$ \\ Departments of ${ }^{1}$ Obstetrics and Gynaecology, and Physiology and ${ }^{2}$ Zoology, The University of \\ Western Ontario, London, Ontario, Canada; and ${ }^{3}$ Department of Medical Biochemistry, \\ University of Calgary, Calgary, Alberta, Canada
}

\begin{abstract}
The sensitive mRNA phenotyping technique of reverse transcription-polymerase chain reaction was used to demonstrate that insulin receptor mRNA is present in rat embryos during the preimplantation period. In addition, mRNA encoding insulin-like growth factor (IGF) type I and type II receptors have also been detected in rat preimplantation embryos. IGF-I mRNA was not detected in preimplantation embryos but was found in oviducts and uteri of prepubertal and early pregnant rats. IGF-II mRNA was present in both embryos and in oviducts and uteri during the preimplantation period. These findings suggest that insulin and IGF-I could influence early embryo development in endocrine or in paracrine fashions, whereas IGF-II may have an additional autocrine mode of action in affecting preimplantation embryos in rats.
\end{abstract}

\section{Introduction}

Early embryonic mortality is a significant contributor to pregnancy failure in many mammalian species (Hafez, 1967; Cooke, 1988). Prevention of early embryonic mortality requires a thorough understanding of the regulation of embryo development. Evidence is accumulating that factors promoting the growth of various types of tissue and cell may also control the growth of early mammalian embryos (Harvey and Kaye, 1988; DeChiara et al., 1990; Paria and Dey, 1990). We previously reported that the addition of insulin to the culture medium improves the development of rat preimplantation embryos in vitro, and that this action of insulin requires the presence of amino acids (Zhang and Armstrong, 1990). The presence of insulin receptors has been demonstrated in eight-cell mouse embryos (Heyner ef al., 1989). In addition, mRNAs encoding insulin-like growth factor (IGF) type I and type II receptors and IGF-II are also present in preimplantation embryos from mice (Rappolee et al., 1990) and cattle (Watson et al., 1992), suggesting that these receptors may transmit possible embryotrophic actions of insulin and IGFs.

A sensitive procedure of reverse transcription-polymerase chain reaction (RT-PCR) was used to examine the presence or absence of mRNA encoding insulin receptors in rat preimplantation embryos to investigate whether the previous observed beneficial effect of insulin on rat embryos was mediated by

\footnotetext{
*Present address and correspondence: Foothills Hospital Regional Fertility Programme, Department of Obstetrics and Gynaecology, University of Calgary, Foothills Professional Building, 1620-29 Street, NW, Calgary, Alberta, T2N 4L7 Canada.

Received 17 March 1993
}

specific receptor binding. The gene transcripts of IGFs I and II and their receptors were also examined for their possible presence in rat embryos and oviducts and uteri (the ligands only) to establish whether the necessary components exist for the autocrine or paracrine regulation of early mammalian development by IGFs.

\section{Materials and Methods}

Collection of embryos and reproductive tracts

Prepubertal Sprague-Dawley rats (26-28 days old) from Charles River Canada (St Constant, Quebec) were induced to ovulate by s.c. injections of $15 \mathrm{iu}$ eCG and, $56 \mathrm{~h}$ later, i.p. injections of $15 \mathrm{iu} \mathrm{hCG}$. Ovulated oocytes were collected from oviducts $16-18 \mathrm{~h}$ after hCG injections and stripped free of cumulus cells in $0.1 \%(\mathrm{w} / \mathrm{v})$ hyaluronidase solution in $\mathrm{Ca}^{2+}$, $\mathrm{Mg}^{2+}$-free phosphate-buffered saline (PBS). To collect embryos, the rats were paired with fertile males of the same strain during the night following hCG injections. Embryos at one-cell, two-cell, four-cell, morula and blastocyst stages were collected from oviducts and uteri at 24, 48, 72, 98 and $120 \mathrm{~h}$, respectively, after hCG injections. The oocytes and embryos were rinsed extensively in $\mathrm{Ca}^{2+}{ }_{-}, \mathrm{Mg}^{2+}$-free $\mathrm{PBS}$ containing $0.3 \%(\mathrm{w} / \mathrm{v})$ polyvinyl pyrrolidone and frozen at $-70^{\circ} \mathrm{C}$ until further processing.

Oviducts and uteri were collected from untreated, prepubertal rats or prepubertal rats at various times after induction of ovulation and fertile matings as for embryo donors. The 
Table 1. Oligonucleotide primers used for RT-PCR

Amplified fragment

Predicted restriction

Gene

Size (bp)

Site

Hincll

IGF Type I receptor

354

Banll

IGF Type II receptor

186

HaeIII

IGF-I

210

MspI

IGF-II
255
SaclI
5' Prir

Primer GTCACTGCAGTCATGCGCATGTGCTGG (nucleotides 3805-3831)

$3^{\prime}$ Primer CCGCCCGTTAAGCTTGCCTCCGTTCAT (nucleotides 4128-4102)

Primer sequence $\left(5^{\prime}-3^{\prime}\right)^{\mathrm{a}}$

Reference

5' Primer ATGCTGTTTGAaCtGCAGCGCATGTGCTGG (nucleotides 3763-3792)

3' Primer CCGCTCGAGCTTGCGGCCCCCGTTCAT (nucleotides 3116-4090)

5' Primer TGTACACTCTTCTTCTGGCA (nucleotides 6946-6965)

3' Primer ACAGATGTTGATGTAGAAGACAGG (nucleotides 7140-7177)

5' Primer GGACCGAGACCCTTTGCGGGG (nucleotides 184-205)

3' Primer GGCTGCTTTTGTAGGCTTCAGTGG (nucleotides 393-370)

5' Primer CGCCCCAGCGAGACTCTGTGC (nucleotides 1142-1162)

3' Primer GCCCACGGGGTATCTGGGGAA (nucleotides 1396-1376)
Ullrich et al., 1985

Ullich et al., 1986

Morgan et al., 1987

Bell et al., 1986

Dull et al., 1984

"Underscored bases indicate mismatches introduced to generate a sticky end restriction site for cloning of PCR fragment. Nucleotide positions in parentheses indicate the location of the primer sequences relative to published cDNA sequences.

${ }^{b}$ Sequences modified slightly from human CDNA sequence on the basis of sequences in rat IGF-II receptor cDNA (D. Morgan, unpublished).

oviducts and uteri were trimmed free of fat, snap-frozen in liquid nitrogen and stored at $-70^{\circ} \mathrm{C}$ for further processing.

\section{RNA extraction}

Oocytes and embryos were pooled according to the stage of development (about 200 for oocytes, one-cell and two-cell embryos, or 150 for four-cell, morula and blastocyst stage embryos) and lysed in $100 \mu \mathrm{l}$ of lysis buffer (4 mol guanidinium thiocyanate $1^{-1} ; 25 \mathrm{mmol}$ sodium citrate $1^{-1}, \mathrm{pH} \mathrm{7;0.1} \mathrm{mol}$ 2-mercaptoethanol $\mathrm{I}^{-1}$ and $0.5 \%(\mathrm{w} / \mathrm{v})$ Sarkosyl). $20 \mu \mathrm{g}$ of Escherichia coli rRNA (Boehringer-Mannheim Canada, Laval) was added to this mixture, which was then layered on to $100 \mu \mathrm{l}$ of a cushion containing $5.7 \mathrm{~mol} \mathrm{CsCl} \mathrm{l^{-1 }}$ and $0.1 \mathrm{~mol}$ EDTA I ${ }^{-1}$. The sample was centrifuged at $247000 \mathrm{~g}$ for $4 \mathrm{~h}$ at $20^{\circ} \mathrm{C}$, using a TL-100 tabletop ultracentrifuge and TLA100 rotor (Beckman Canada, Mississauga), as described by Rappolee et al. (1989). The resultant RNA pellet was dissolved in $100 \mu \mathrm{l}$ of $2.5 \mathrm{~mol}$ ammonium acetate $\mathrm{I}^{-1}$ and precipitated overnight at $-20^{\circ} \mathrm{C}$ after adding $300 \mu \mathrm{l}$ isopropyl alcohol. The RNA was pelleted by centrifugation at $10000 \mathrm{~g}$ for $20 \mathrm{~min}$, rinsed with $70 \%(\mathrm{v} / \mathrm{v})$ ethanol and left to air-dry.

For oviducts and uteri, the tissue was first homogenized in the lysis buffer and then layered over $\mathrm{CsCl}$ to obtain $\mathrm{RNA}$ as for oocytes and embryos.

\section{Reverse transcription $(R T)$ and polymerase chain reaction $(P C R)$}

Total RNA from 150-200 oocytes and embryos and $0.5 \mu \mathrm{g}$ oviductal and uterine RNA were reverse transcribed by incubation at $42^{\circ} \mathrm{C}$ for $1.5 \mathrm{~h}$ in a $20 \mu \mathrm{l}$ mixture consisting of $50 \mathrm{mmol}$ Tris $\mathrm{I}^{-1}, \mathrm{pH} 8.3,60 \mathrm{mmol} \mathrm{KCl} \mathrm{l^{-1 }}, 10 \mathrm{mmol}$ DTT $\mathrm{I}^{-1}, 3 \mathrm{mmol} \mathrm{MgCl}_{2} \mathrm{I}^{-1}, 20 \mathrm{ng}$ oligo-dT (Pharmacia Canada, Montreal) $\mu \mathrm{l}^{-1}$, I mmol each of dATP, dCTP, dGTP and dTTP $1^{-1}$ (Pharmacia Canada), 2 U RNAase inhibitor (RNAsin, Promega, Madison, WI) $\mu^{-1}$, and $1.5 \mathrm{U}$ avian myeloblastosis virus reverse transcriptase (Boehringer-Mannheim Canada) $\mu \mathrm{I}^{-1}$. The reaction was terminated by heating at $90^{\circ} \mathrm{C}$ for $5 \mathrm{~min}$ and quickly cooling in ice.

An aliquot $(1.0 \mu \mathrm{l})$ of this RT reaction mix was used for PCR in a final volume of $50 \mu \mathrm{l}$ containing $10 \mathrm{mmol}$ Tris- $\mathrm{HCl} \mathrm{l}^{-1}$, pH 8.3, $50 \mathrm{mmol} \mathrm{KCl}^{-1}, 1.5 \mathrm{mmol} \mathrm{MgCl}_{2} 1^{-1}, 0.001 \%$ (w/v) gelatin, $0.2 \mathrm{mmol}$ each of $\mathrm{dNTP} 1^{-1}, 1 \mu \mathrm{mol}$ each of PCR primers $\mathrm{I}^{-1}$ (see below) and $2.5 \mathrm{U}$ Taq DNA polymerase (Gibco-BRL Canada, Burlington). The PCR reaction was covered with $60 \mu \mathrm{l}$ mineral oil and subjected to $30-40$ cycles in a DNA thermal cycler (Perkin Elmer-Cetus, Norwalk, CT) where each amplification cycle consisted of denaturing at $94^{\circ} \mathrm{C}$ for $1 \mathrm{~min}$, annealing of primers to target sequence at $55-65^{\circ} \mathrm{C}$ for $2 \mathrm{~min}$ and primer extension at $72^{\circ} \mathrm{C}$ for $2 \mathrm{~min}$.

An aliquot (15-20 $\mu$ l) of the PCR products was analysed by electrophoresis on $7 \%$ polyacrylamide or $2 \%$ agarose gels and 
(a)

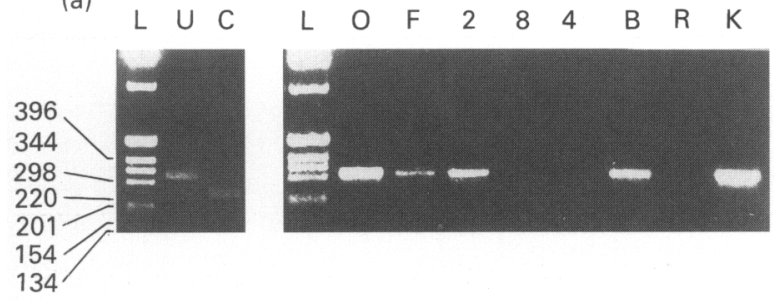

(b) $\quad \begin{array}{lllllllll}\mathrm{O} & \mathrm{F} & 2 & 8 & 4 & \mathrm{~B} & \mathrm{R} & \mathrm{K}\end{array}$

Insulin receptor

(c)

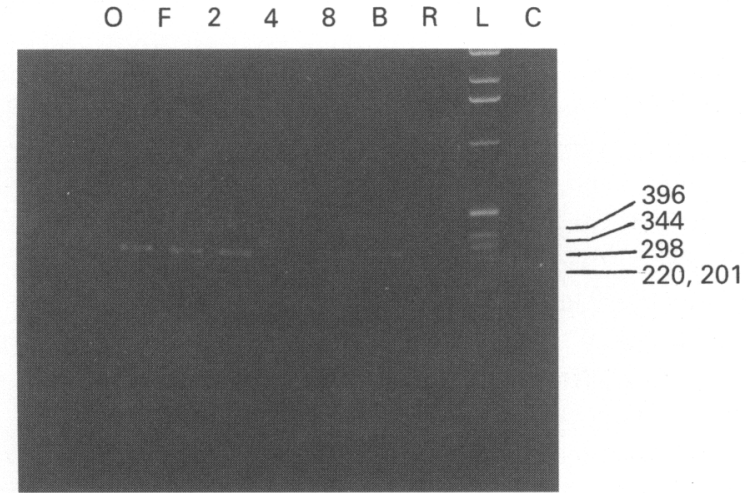

Fig. 1. Insulin receptor mRNA in oocytes and embryos. Approximately 20 oocytes (O), 20 embryos at one-cell (F) or two-cell (2) stages, or 15 embryos at eight-cell (8), four-cell (4) or blastocyst (B) stages were subjected to reverse transcription-polymerase chain reaction ( $R T-P C R)$. The medium in which the oocytes or embryos were rinsed before RNA extraction was subjected to the same (RT-PCR) procedures as a negative control (R). A sample of rat kidney $\mathrm{CDNA}$ was included as a positive control $(\mathrm{K})$. The values indicate the numbers of base pairs for some of the DNA fragments in a $1 \mathrm{~Kb}$ DNA ladder (L). (a) Electrophoresis and ethidium bromide staining of PCR products after a 30-cycle amplification. The amplification signal was verified by digestion with HincIl to yield expected fragment sizes of 255 and $69 \mathrm{bp}$ (the latter fragment was not clearly visible in the gel, probably because of its small size); an example of the digestion of a PCR product from a one-cell embryo (F) is shown on the left (U; uncut; C: cut). (b) Southern blot analysis of the gel in (a) using a ${ }^{32}$ P-labelled cDNA probe for the human insulin receptor. (c) Electrophoresis and ethidium bromide staining of PCR products after a 40 -cycle amplification.

stained with ethidium bromide to visualize PCR products on a UV transluminator. The authenticity of the PCR products with the anticipated sizes was further verified by either digestion with restriction endonucleases specific for sequences bracketed by the PCR primers, or Southern blot analysis after the PCR products were transferred from an electrophoresis gel to a nylon membrane, as described by Telford et al. (1990a) and Watson et al. (1992).

The PCR primers used in the present study were designed and synthesized as reported by Telford et al. (1990a) and

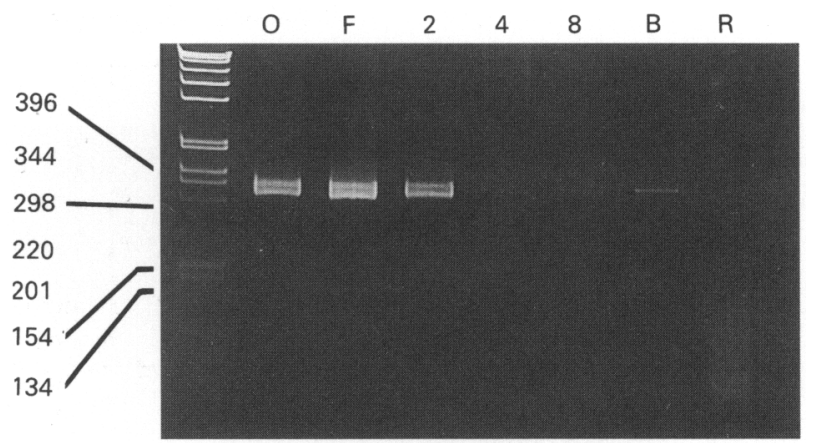

Fig. 2. Insulin-like growth factor (IGF) type I receptor mRNA in oocytes and embryos. A 30-cycle amplification was performed on samples equivalent to approximately 20 oocytes (O), 20 embryos at one-cell (F) or two-cell (2) stages, or 15 embryos at four-cell (4), eight-cell (8) or blastocyst (B) stages. The medium in which the oocytes or embryos were rinsed before RNA extraction was subjected to the same reverse transcription-polymerase chain reaction (RT-PCR) procedures as a negative control (R).

Watson et al. (1992). The nucleotide sequences of these primers are shown in Table 1 .

\section{Results}

All RNA preparations were evaluated by first determining the presence of a relatively abundant mRNA, $\beta$-actin mRNA, before the gene of interest was studied. An aliquot of each RNA preparation was also subjected to the RT-PCR procedure, with the omission of reverse transcriptase during the RT reaction. No amplification product was detected in such samples using the PCR primers selected for this study (results not shown). This finding indicates that the amplified signal in our cDNA preparations was not due to the presence of genomic DNA.

After an amplification of 30 cycles, a PCR product corresponding to the insulin receptor mRNA was visualized by ethidium bromide staining in oocytes, one-cell and two-cell embryos and blastocysts (Fig. Ia). Southern blot analysis using a radiolabelled $\mathrm{cDNA}$ probe for human insulin receptor (Ullich et al., 1985) confirmed the authenticity of the PCR product, and also detected insulin receptor mRNA signals in four-cell and eight-cell embryos (Fig. Ib). The presence of low amounts of insulin receptor mRNA in four-cell and eight-cell embryos was further demonstrated when the PCR was continued for 40 cycles (Fig. Ic).

Messenger RNA encoding the IGF type I receptor was also detected in oocytes, one-cell and two-cell embryos and blastocysts (Fig. 2). The signals in four- and eight-cell embryos were too weak to be visualized easily. This was not improved by increasing the number of PCR cycles, due to the presence of a non-specific band (the lower band). This non-specific band has also been observed in other studies on mouse and bovine embryos using the same PCR primers (Telford et al., 1990a; Watson et al., 1992), and is caused by a crossreaction between the primers and insulin receptor cDNA sequences (Telford et al, 1990a). Differential digestion with 


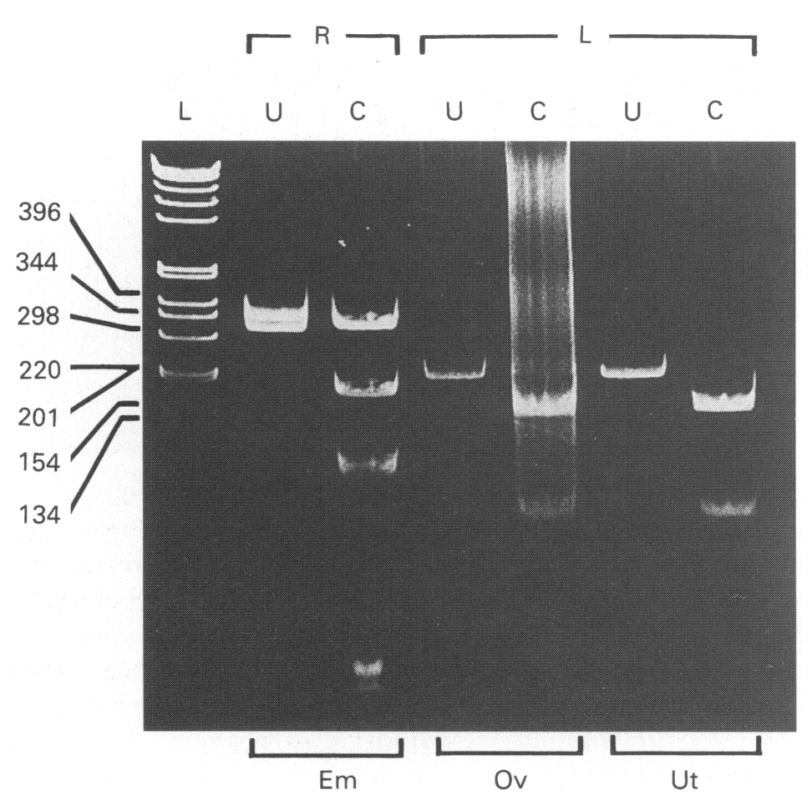

Fig. 3. Verification of polymerase chain reaction (PCR) products. Banll and Mspl were used to digest PCR products corresponding to insulin-like growth factor (IGF) type I receptor mRNA ( $R, 354 \mathrm{bp}$ ) and IGF-I mRNA (L, $210 \mathrm{bp}$ ), respectively. L: $1 \mathrm{~kb}$ ladder; $U$ : uncut; $C$ : cut; Em: embryo (Lane $O$ in Fig. 2); Ov: oviduct (Lane $T 1$ in Fig. 4); Ut: uterus (Lane U1 in Fig. 4). The fragments in the C lane for the IGF-I receptor represent the uncut insulin-receptor PCR product (324 bp) and fragments from BanIl digestion of the IGF-I receptor PCR products.

Banll (Fig. 3) verified that the upper band (354 bp) represents the amplification product corresponding to the mRNA encoding the IGF type I receptor.

IGF-I mRNA was not detected in oocytes or preimplantation embryos after a 40-cycle amplification. This was not due to the failure of the experimental procedures, because in each experiment a rat kidney sample, included as a control, always yielded a PCR product corresponding to IGF-I mRNA. Furthermore,
IGF-I mRNA was detected in oviducts and uteri (Fig. 4), and the authenticity of the PCR product was confirmed by digestion with Mspl (Fig. 3).

IGF type II receptor mRNA was present in oocytes and embryos of all stages, and digestion with HaelII produced diagnostic fragments of the expected size (Fig. 5). IGF-II mRNA (Fig. 6) was present in oocytes and embryos of all the stages tested. The PCR product was verified by digestion with SacIl (Fig. 6).

\section{Discussion}

Insulin and IGFs are a group of structurally related polypeptides that regulate the growth of many types of mammalian cell (reviewed by Froesch et al., 1985; and Czech, 1989). The growth-promoting actions of these polypeptides are mediated by binding to receptors on the cell membrane, and receptors with primary binding specificity for the polypeptides have been identified (reviewed by Baxter, 1988). IGF-I has a higher binding affinity for the type I receptor than for the type II receptor, and IGF-II has a higher binding affinity for the type II receptor than for the type I receptor. Insulin can also interact with the type I receptor. The present study demonstrates the presence of mRNA encoding the insulin receptor in preimplantation rat embryos, and provides supporting evidence that the previously observed beneficial effect of insulin on rat embryo development could be mediated through its specific receptor. The genes encoding IGF type I and type II receptors are also expressed in rat oocytes and preimplantation embryos at some (for type I receptor) or all stages examined. This suggests that, as in mice (Dechiara et al., 1990; Harvey and Kaye, 1988), IGFs also play a role in normal preimplantation development in the rat by interacting with their specific receptors in the embryo.

IGFs are produced by many tissues of the body and therefore can act in a paracrine or autocrine fashion in addition to the endocrine mode of action that is used by insulin (D'Ercole et al, 1984). Thus, while bloodborne insulin may transude across the reproductive tract to exert its action on rat
IGF-I

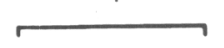

U

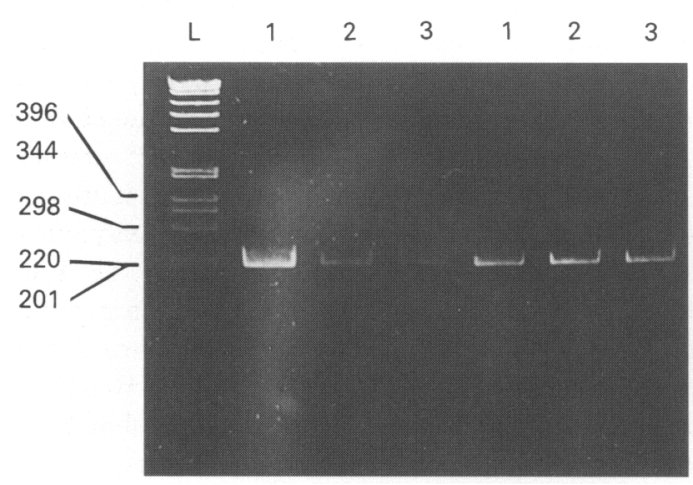

IGF-II

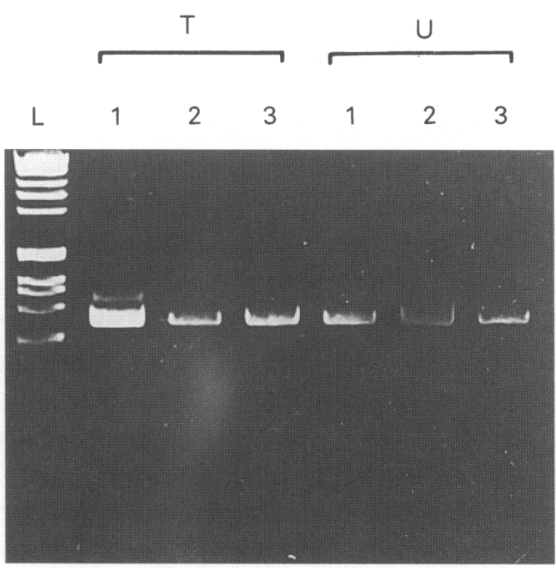

Fig. 4. Insulin-like growth factor (IGF) type I and II mRNA in oviducts and uteri. A 30-cycle amplification was performed on samples of oviducts $(T)$ or uteri $(U)$ from untreated, prepubertal rats (I), or rats on day $2(2)$ or day 5 (3) of pregnancy (day 1: presence of copulatory plug or spermatozoa in vagina). L: $1 \mathrm{~kb}$ ladder. 


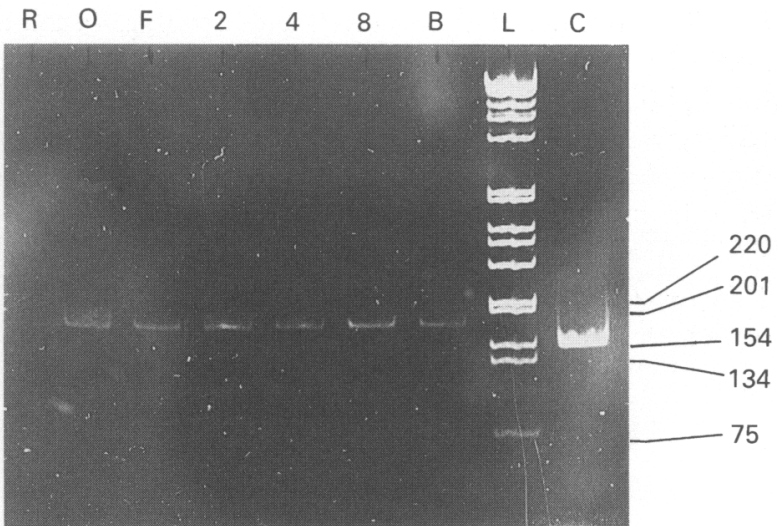

Fig. 5. Insulin-like growth factor (IGF) type II receptor mRNA in oocytes and embryos. A 30-cycle amplification was performed on samples equivalent to approximately 20 oocytes (O), 20 embryos at one-cell (F) or two-cell (2) stages, or 15 embryos at four-cell (4), eight-cell (8) or blastocyst (B) stages. The medium in which the oocytes or embryos were rinsed before RNA extraction was subjected to the same reverse transcription-polymerase chain reaction (RT$P C R$ ) procedures as a negative control $(R)$. The $P C R$ products were verified by digestion with HaelII to yield the expected 152 and $34 \mathrm{bp}$ fragments (the latter fragment was not clearly visible in the gel, probably because of its small size); an example of the digestion of a PCR product from a one-cell embryo (F) is shown to the right of the $\mathrm{I} \mathrm{kb}$ ladder (C). L: $\mathrm{I} \mathrm{kb}$ ladder.

embryos, IGFs that are destined to interact with embryos may come from the general blood circulation, the reproductive tract or embryos. The present study did not examine whether insulin mRNA is present in embryos or the reproductive tract. However, insulin mRNA was not detected in preimplantation embryos from mice (Rappolee et al., 1990). IGF-I mRNA could not be detected in preimplantation embryos in the present study, which is consistent with the absence of this mRNA in preimplantation mouse embryos (Rappolee $e t$ al., 1990). This indicates that an autocrine mechanism is not the likely mode of action for this polypeptide during preimplantation development. The oviduct and uterus are possible sources for IGF-I, since its mRNA is detected in these two tissues. For IGF-II, both autocrine and paracrine interactions may mediate its action since its mRNA is present in preimplantation embryos and the reproductive tract. The present study did not examine whether the IGF mRNAs are translated in the reproductive tract. If these IGF polypeptides are present, their actions on embryo development would be further regulated by various IGF binding proteins, which have yet to be studied in this context.

Preimplantation development of embryos from many mammalian species can be maintained in vitro, independent of the maternal environment. However, the rate of embryo development in vitro is impaired to various degrees depending on the species and can be improved by co-culture with oviductal or uterine cells as well as with some other types of cell (Bavister, 1988). This finding suggests that mammalian embryos have certain autonomy in regulating their early development, but that optimal development is obtained by support from their physiological environment. This hypothesis for the control of early mammalian development is well supported by the present

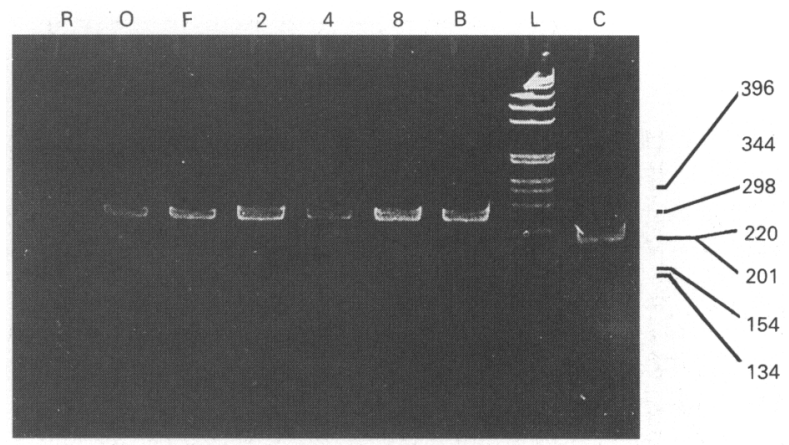

Fig. 6. Insulin-like growth factor (IGF) type II mRNA in oocytes and embryos. A 30-cycle amplification was performed on samples equivalent to approximately 20 oocytes $(\mathrm{O}), 20$ embryos at one-cell $(\mathrm{F})$ or 2-cell (2) stages, or 15 embryos at 4-cell (4), 8-cell (8) or blastocyst (B) stages. The medium in which the oocytes or embryos were rinsed before RNA extraction was subjected to the same reverse transcription-polymerase chain reaction (RT-PCR) procedures as a negative control $(R)$. The PCR products were verified by digestion with SacII to yield expected fragments of 189 and $67 \mathrm{bp}$; an example of the digestion of a PCR product from a one-cell embryo $(F)$ is shown to the right of the $\mathrm{I} \mathrm{kb}$ ladder $(\mathrm{C})$. L: I kb ladder.

data on gene expression for the receptors of insulin and IGFs as well as IGF ligands. Thus, while IGF-II may be a component of autonomous regulation, IGF-I and insulin are very likely to be some of the possible maternal regulators of preimplantation development. Further evidence that insulin plays an important role in early development comes from experiments in which mice or rats have been made insulin-deficient through streptozotocin treatment. Blastocysts collected from such diabetic mothers have fewer cells than do their normal counterparts (Pampfer et al., 1990; Beebe and Kaye, 1991).

Some of the earliest mammalian developmental events are controlled by maternal products accumulated within the oocyte during oogenesis. These inherited maternal transcripts undergo a degradation process to be replaced by transcripts of the embryonic genome at various species-specific stages of early cleavage (Telford et al., 1990b). In mouse embryos, the transition from maternal to embryonic genome control occurs after the first cell division, and this transition is often reflected in the changing levels of many mRNA species at the two-cell stage. For example, the amount of $\beta$-actin mRNA decreases at the early two-cell stage, as a result of the breakdown of maternal transcripts in embryos, and increases thereafter as a result of the activation of the embryonic genome (Giebelhaus et al., 1983; Graves et al., 1985). In the study by Rappolee et al. (1990), none of the genes that were examined in the present study was expressed in mouse embryos before the two-cell stage (i.e. before activation of the embryonic genome), suggesting that maternal transcripts of these genes are not inherited by mouse embryos. The results from the present study suggest that this is not the case for the early rat embryo since maternal messages for some of the growth factors (i.e. mRNAs encoding IGF-II and receptors for insulin and IGFs) were observed in unfertilized rat oocytes and embryos.

Similar differences in the patterns of gene expression were also reported between bovine embryos and mouse embryos (Watson ef al., 1992), suggesting that growth factors may exert 
an influence on preimplantation development in many mammalian species earlier than that reported in mice. Although no definitive evidence is available for the time of activation of the embryonic genome in rats, it appears to occur after the two-cell stage as in mice. The low concentration of mRNA encoding the insulin receptor and IGF type I receptor in four-cell and eight-cell embryos may be due to a delay in activation of these genes in the embryonic genome.

This study takes advantage of the highly sensitive RT-PCR procedure to analyse gene expression in early mammalian embryos that often cannot be analysed biochemically because of the scarcity of experimental material. Further studies are required to verify the translational status of the mRNAs that are studied in this report. This will help confirm the physiological significance of insulin and IGFs in the regulation of early embryo development.

The authors wish to thank J. Rutledge for her skilful technical assistance and the Medical Research Council of Canada for financial support. D. T. Armstrong is a Career Investigator of MRC of Canada and $X$. Zhang was assisted by a Wyeth Fellowship during the course of this study.

\section{References}

Bavister BD (1988) Role of oviductal secretions in embryonic growth in vivo and in vitro Theriogenology 29 143-154

Baxter RC (1988) The insulin-like growth factors and their binding proteins Comparative Biochemistry and Physiology 91 229-235

Beebe LFS and Kaye PL (1991) Maternal diabetes and retarded preimplantation development of mice Diabetes 30 457-46I

Bell GI, Stempien MM, Fong NM and RaIl LB (1986) Sequences of liver cDNAs encoding two different mouse insulin-like growth factor I precursors. Nucleic Acids Research 14 7873-7882

Cooke ID (1988) Failure of implantation and its relevance to subfertility Journal of Reproduction and Fertility Supplement 36 155-159

Czech MP (1989) Signal transmission by the insulin-like growth factors. Cell 59 $235-238$

DeChiara TM, Efstatiadis A and Robertson EJ (1990) A growth deficiency phenotype in heterozygotic mice carrying an insulin-like growth factor II gene disrupted by targeting Nature 345 78-80

D'Ercole AJ, Stiles AD and Underwood LE (1984) Tissue concentrations of somatomedin C: further evidence for multiple sites of synthesis and paracrine or autocrine mechanisms of action Proceedings of the National Academy of Sciences USA $\mathbf{8 1}$ 935-939

Dull TJ, Gray A, Hayflick JS and Ullrich A (1984) Insulin-like growth factor II precursor gene organization in relation to insulin gene family Nature $\mathbf{3 1 0}$ $777-781$

Froesch ER, Schmid C, Schwander J and Zapf J (1985) Actions of insulin-like growth factors Annual Review of Physiology 47 443-467

Giebelhaus DH, Heikkila JJ and Schultz GA (1983) Changes in the quantity of histone and actin messenger RNA during development of preimplantation mouse embryos Developmental Biology 98 148-154
Graves RA, Marzluff WF, Giebelhaus DH and Schultz GA (1985) Quantitative and qualitative changes in histone gene expression during mouse embryo development Proceedings of the National Academy of Sciences USA $\mathbf{8 2}$ 5685-5689

Hafez ESE (1967) Reproductive failure in domestic mammals Comparative Aspects of Reproductive Failure, pp 44-95 Ed. K Benirschke. Springer-Verlag, Berlin

Harvey MB and Kaye PL (1988) Insulin stimulates protein synthesis in compacted mouse embryos Endocrinology 122 1182-1184

Heyner S, Rao LV, Jarett L and Smith RM (1989) Preimplantation mouse embryos internalize maternal insulin via receptor-mediated endocytosis: pattern of uptake and functional correlations Developmental Biology 134 $48-58$

Morgan DO, Edman JC, Standring DN, Fried VA, Smith MC, Roth RA and Rutter WJ (1987) Insulin-like growth factor II receptor as a multifunctional binding protein Nature 329 301-307

Pampfer S, De Hertogh R, Vanderhyden I, Michiels B and Vercheval M (1990) Decreased inner cell mass proportion in blastocysts from diabetic rats Diabetes 29 471-476

Paria BC and Dey SK (1990) Preimplantation development in vitro: cooperative interactions among embryos and role of growth factors Proceedings of the National Academy of Sciences USA 87 4756-4760

Rappolee DA, Wang A, Mark D and Werb Z (1989) A novel method for studying mRNA phenotypes in single or small numbers of cells Journal of Cellular Biochemistry 39 1-11

Rappolee DA, Sturm K, Schultz GA, Pedersen RA and Werb Z (1990) The expression of growth factor ligands and receptors in preimplantation mouse embryos UCLA Symposia on Molecular and Cellular Biology (New Series: Early Embryo Development and Paracrine Relationships), Vol. 117 pp 11-26 Eds S Heyner and L Wiley. Alan R Liss, New York

Telford NA, Hogan A, Franz CR and Schultz GA (1990a) Expression of genes for insulin and insulin-like growth factors and receptors in early postimplantation mouse embryos and embryonal carcinoma cells Molecular Reproduction and Development 27 81-92

Telford NA, Watson AJ and Schultz GA (1990b) Transition from maternal to embryonic control in early mammalian development: a comparison of several species Molecular Reproduction and Development 26 90-100

Ullrich A, Bell J, Chen E, Herrera R, Petruzelli LM, Dull TJ, Gray A, Coussens L, Liao $Y$, Tsubokawa M, Mason A, Seeburg P, Grunfeld $C$, Rosen $O$ and Ramachandran J (1985) Human insulin receptor and its relationship to the tyrosine kinase family of oncogens Nature 313 756-761

Ullrich A, Gray A, Tam A, Yang-Geng T, Tsubokawa M, Collins C, Henzel W, LeBon T, Kathuria S, Chen E, Jacobs S, Francke U, Ramachandran J and Fujita-Yamaguchi $Y$ (1986) Insulin-like growth factor I receptor primary structure: comparison with insulin receptor suggests structural determinants that define functional specificity European Molecular Biology Organisation Joumal 5 2503-2512

Watson AJ, Hogan A, Hahnel A, Wiemer KE and Schultz GA (1992) Expression of growth factor ligand and receptor genes in the preimplantation bovine embryo Molecular Reproduction and Development 31 231-240

Zhang X and Armstrong DT (1990) Presence of amino acids and insulin in a chemically defined medium improves development of 8-cell rat embryos in vitro and subsequent implantation in vivo Biology of Reproduction $\mathbf{4 2}$ $662-668$ 